\title{
CLIMATE VARIABILITY AND RESIDENTS MORBIDITY IN OGBOMOSO NIGERIA
}

\author{
AKINDELE O. AKIN
}

Urban and Regional Planning Department, Ladoke Akintola University of Technology, Ogbomoso, Oyo State Nigeria

ABSTRACT
This paper investigates the climate change contribution to residents' morbidity in Ogbomoso, Nigeria. The trend
in the variation of climatic data, climate and environmentally related morbidity were put into the analysis. Primary and
secondary data were used. The bulk of the primary data was obtained by administering a questionnaire to 347
respondents using a multistage sampling technique. Hospital records and climatic data were obtained from the relevant
governmental agencies and hospitals. Likert scaling was used to treat the ordinal data. Climatic data showing variation
over the years was regressed on incidence of climate related morbidity over the same year period. It was observed that
there is a reliable relationship between climate change and residents morbidity (R=6. 8 ) at $\alpha=05$. The paper thus
suggests environmental greenery through parks, gardens, soft landscape among others, to placate the increasing
temperature and CO ${ }_{2}$ production towards a better living environment.
KEYWORDS: Parks, Gardens \& Soft Landscape

Received: Nov 30, 2016; Accepted: Dec 17, 2016; Published: May 13, 2017; Paper Id.: IJEEFUSJUN20171

\section{INTRODUCTION}

One of the current most prominent issues among the professional in the field of the built environment is the state of the global environment; particularly climate change (Parrish 1993; UN-Habitat, 2011). This has provoked increasing anxiety about the well being of the environment and its inhabitants. The world's emphasis on health has shifted from curative to preventive measures (NIH, 2009). Preventing urban residents from disease forces a closer gaze on the issues of climate change (Adeboyejo, 2012). The major public health organizations of the world have observed climate change to be critically contributing to public health problems, ingraining many existing diseases and encouraging the introduction of new pests and pathogens into new regions or communities (Balbus 2011).

The current pace of temperature increase as well as the concentration of heat trapping gases outstrips record history, and the decrease in the yearly intervals between major temperature change has become monumental (Alexander, 2006; Schmidt, 2014). A 4-7º $\mathrm{C}$ global temperature increase over a period of 5,000 years, escorted the world out of ice ages. Recently, the unprecedented global temperature increase is about 10 times faster (The Guardian, 2016; Genthon, 1987; USGCRP, 2009). Global temperature now perilous peaks at $1.38^{\mathrm{OC}}$ above the 1900s. Keeping the temperature increase within the guardrail about $1.5^{\circ} \mathrm{C}$ has been impossible; implying a chronic problem for the future society (The Guardian, 2016; Dodman and Satterthwaite, 2009). In a conservative sense, the world will heat up 20 times faster than the historical average in another century. Protracted emission of carbon dioxide would raise sea levels approximately by $70 \mathrm{ft}$ in the next centuries shrinking the polar ice caps, making large 
areas of the Middle East and North Africa unlivable and hasten the sixth animal species mass extinction (The Guardian, 2016; UN-Habitat, 2011; Alley, 2002).

Climate change has been observed to be sponsored by human activities that have consistently increased carbon dioxide $\left(\mathrm{CO}_{2}\right)$ production in this contemporary time, $\left(\mathrm{CO}_{2}\right)$ has increased to 394 parts per million (ppm) as at mid-2012 (NOAA's Mauna Loa Observatory in Hawaii, 2012; IPCC, 2008); triggering large scale environmental hazards, human health impairment, ozone layer depletion, loss of biodiversity, stresses to food production systems and the global spread of infectious diseases. More than 160,000 deaths since 1950 are directly attributable to climate change (WHO, 2008). Climate change is already responsible for 300,000 deaths a year and is affecting 300m people. The increasingly severe heat waves, flood, storms and forest fires will be responsible for as many as 500,000 deaths a year by 2030 making it the greatest humanitarian challenges the world faces (Sachs 2012).

Weather related disasters brought about hunger, diseases, poverty and lost livelihoods. Four billion people are vulnerable now and 500 million people are at extreme risk. (Margareta 2012). If climate change is not brought under control, within 25years, 310 million people will suffer adverse health consequences related to temperature increase, 20million more people will fall into poverty and 75 million people will be homeless (Rajendra Pachauri 2012). Global warming is creating conditions that lead to potentially fatal malnutrition and diarrhea. It increases the likelihood of heat waves and floods (WHO, 2008). In 1998, Hurricane Mitch dropped six feet of rain on Central America in three days. In its wake, the incidence of malaria, dengue fever, cholera, and leptospirosis soared. In 2000, rain and three cyclones covered Mozambique with water for six weeks, and the incidence of malaria rose fivefold. In 2003, a summer heat wave in Europe killed tens of thousands of people, wilted crops, set forests ablaze, and melted 10 percent of the Alpine glacial mass (Epstein 2015).

Nigerian cities including Ogbomoso have been affected by gradual changes in climate and weather condition, and this has the propensity to cause adverse effects on people's health (Akpofure, et al 2009). Thus, the rate at which people are visiting or been admitted into hospitals for treatment of various diseases such as diarrhea, typhoid, malaria, cancer among many others has been on the increase. It thus becomes pertinent to ask: how serious is climate change related morbidity in the local environment of ogbomoso? How much do these health problems relate to weather variability? Are residents in the rainforest as vulnerable? What particular type of sicknesses is climate change induced? Answers to these and other related questions from the tenet of this paper. The paper therefore assesses the morbidity dimensions of climate change in Ogbomoso Nigeria, with a view to proffering necessary solutions to the predicted challenges of climate change.

\section{Climate Change, Health and Environment}

Throughout the world, the prevalence of some diseases and other threats to human health depend largely on local climate. Extreme temperatures can lead directly to loss of life, while climate related disturbances in ecological system, such as changes in the rate of ineffective parasites, can indirectly impact the incidence of serious infectious diseases. In addition, warm temperatures can increase air and water pollution, which in turn harm human health. While it is agreed that human health is borne by a large composite of factors, it is a truism that health and environmental conditions are largely related.

The extent and nature of climate change impacts on human health vary by region, by relative, vulnerability of population groups, by the extent and duration of exposure to climate change itself and by society's ability to adapt to or 
cope with the change. Moreover, the human being is exposed to climate change through changing weather patterns (for example, more intense and frequent extreme events) and indirectly through changes in water, air, food and water quality and quantity, ecosystem, agriculture and economy. At this stage, the effects are small but are projected to progressively increase in all countries and regions.

High frequency of algae blooming has been associated with a warmer temperature. This has the propensity to aggravate the problems of cholera, malaria; dengue yellow fever and encephalitis as the proliferation of vectors such as Ascariasis, Blastocytis hominies, dog tapeworm, Enterobiasis or pinworm infection, Filariasis, Giardia, guinea worm, leishmaniosis, Schistosoma, Strongylodiasis, Trichuriasis are favored. Warmer temperature may prolong disease transmission, exacerbate respiratory disorders and contribute to air quality problems (IPCC 2007). Regional climate change impacts agricultural yield and production, increasing the number of undernourished people globally and consequently leading to complications in child development.

In a warmer world, climate change makes heat waves more frequent and severe. The young, the elderly, the women, the poor, the frail, and those who live on the top floors of apartment buildings are particularly vulnerable. For instance, a $7.8^{\circ} \mathrm{C}$ rise in average daily temperature during a heat wave resulted in excess mortality both in New York and France; killing more elderly women. This could be worse in warmer developing countries where medical facilities are inadequate. For instance, air pollution (through increased acid precipitation, particulates and smog) currently harms more than 1.1 billion people and kills three million annually. Ninety percent of these deaths occur in warmer developing countries.

\section{RESEARCH METHODOLOGY}

The study necessarily relied on primary and secondary data. While meteorological data and records from hospitals considered local and particular to the area studied are the secondary data, information elicited from the residents formed the bulk of the primary data analyst. After a reconnaissance survey, a structured questionnaire was administered pro-route to a total of 347 residents, using a multi-stage sampling procedure across the wards; eliciting information on issues of climate change and health. The quantitative data were analyzed, largely summarized with the aid of Likert scaling. Data regarding perception in this study was collected using the structured questionnaire in the ordinal ranking form. It follows that, for each ward, the number of respondents multiplied by 4 is the maximum point achievable from each variable. This was used to standardize the weighing of the responses from the residents. The total score for each variable, divided by the maximum point achievable multiplied by 100 becomes the standardized score for each variable. Since the answers will be different because of the difference in the individual mean of the variables, a mean average was computed for use as general mean for all the variables in the table. Thus, each composite figure is given by:

$$
\begin{aligned}
& \mathrm{N}_{1} \quad \mathrm{~N} 2 \quad \mathrm{~N} 3 \\
& \sum \mathrm{d} 1+\sum \mathrm{e} 1+\sum \mathrm{m} 1 \\
& \mathrm{i}=1 \quad \mathrm{i}=1 \quad \mathrm{i}=1 \\
& \left\{\begin{array}{l}
\mathrm{N}_{1} \\
\mathrm{~N}_{2}
\end{array} \mathrm{~N}_{3}\right. \\
& \sum \mathrm{D} 1+\sum_{1}
\end{aligned}
$$


$\mathrm{i}=1 \quad \mathrm{i}=1 \quad \mathrm{i}=1$

Where: N1, N2 and N3are the variables selected for scaling, $d$, e and $\mathrm{m}$ are the actual score of the variables and D $\mathrm{E} \mathrm{M}$ are the maximum point that may be scored by the variables.

Descriptive and inferential statistics were used to explain the observations. Chi- square was used to explain the variations in environmental literacy and quality and environmental literacy, among the sampled wards. Regression analysis was used to explain the relationship between incidence of climate change and morbidity.

\section{Incidence of Climate Change}

While it is difficult to take the climatic data at different points within the city, a localized climatic data of a defined place over a period of time becomes useful for the analysis. To this end, the available climatic data over a ten year period was obtained from the state's meteorological station. It is visible from the table that elements of climate have been on the increase over the 10 year period. This is especially true of rainfall and relative humidity. While it may be observed that the growth in temperature is not steady and that fluctuations are evident from year to year, yet, with careful observations, it would be seen that temperature has increased over the 10 year period. Generally, therefore, climatic parameters that are indicative of climate change have been on the gradual increase.

Table 1: Climate Variability Data

\begin{tabular}{|c|c|c|c|c|c|c|}
\hline \multicolumn{7}{|c|}{ Climate Data for Ibadan } \\
\hline Year & $\begin{array}{c}\text { Record High } \\
\left({ }^{0} \mathrm{c}\right)\end{array}$ & $\begin{array}{c}\text { Record Low } \\
\text { ('c) }\end{array}$ & $\begin{array}{l}\text { Average } \\
\text { High ( }\left(^{0} \mathrm{c}\right)\end{array}$ & $\begin{array}{l}\text { Average } \\
\text { Low ( ( }) \text { c) }\end{array}$ & Rainfall (m) & Humidity (\%) \\
\hline 2006 & 444 & 100 & 396 & 252 & 96 & 76 \\
\hline 2007 & 468 & 120 & 408 & 264 & 276 & 71 \\
\hline 2008 & 456 & 180 & 408 & 276 & 912 & 75 \\
\hline 2009 & 456 & 180 & 396 & 276 & 1500 & 78 \\
\hline 2010 & 400 & 180 & 384 & 264 & 1740 & 82 \\
\hline 2011 & 396 & 180 & 348 & 264 & 1956 & 86 \\
\hline 2012 & 372 & 180 & 336 & 252 & 1584 & 88 \\
\hline 2013 & 372 & 180 & 324 & 252 & 888 & 88 \\
\hline 2014 & 432 & 170 & 448 & 264 & 240 & 86 \\
\hline 2015 & 496 & 180 & 460 & 264 & 1824 & 84 \\
\hline
\end{tabular}

Source: Oyo State Meteorological Services, 2016.

To project a clearer picture of climate change using parameters of temperature and rainfall, it becomes necessary to plot the graph of both parameters showing how they increased over the decade. It will be observed that (Figure 1) both the temperature and rainfall has been on the increase. Rainfall increased significantly between the year 2006 to 2011 . It decreased temporarily between 2011to 2014 but increased sharply between 2014 and 2015. Similarly, an increase in temperature was observed from the year 2006 until 2009 when it decreases sharply but to rise steadily through 2015. 


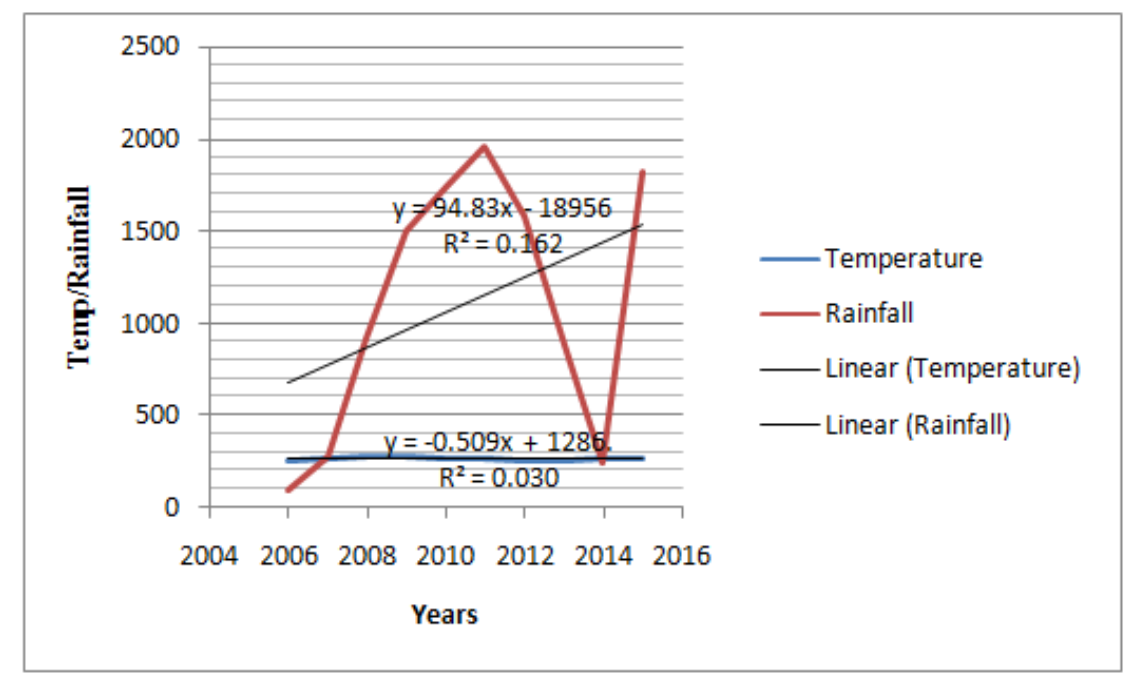

Figure 1: Temperature and Rainfall Dynamics over 10Yrs

Source: Author's Device, 2016

It may be deduced that temperature and rainfall varies directly and increase in one influences increase in the other.

This magnifies why sustainable management of one would help the other. It is therefore advocated here that measures such as sustainable environmental greening, cut in carbon emission and other heat trapping gases be encouraged. This would positively affect other environmental components such as air composition, precipitation make our planet more liveable as well as conceivable to be bequeathed to next generations.

\section{Incidence of Diseases that may be Related to Climate Change}

Two approaches were used to investigate the diseases that may be related to climate change: residents" observation as well as hospital records became important to the understanding the said diseases in the study. Residents' observation data was taken either in ordinal or nominal form. Necessarily, therefore, the sum of the weight was computed and standardized. The final result is presented in table 2. The incidence of each of the climate change-related diseases was investigated. Chi-square was used to explain the difference in the incidence of diseases across the wards. It is intuitive that neighbourhood characteristics vary from ward to ward and so would be climate change mitigating properties of the areas. This was hypothesized to mark the difference in the incidence of diseases among the wards.

Table 2: Occurrence of Diseases

\begin{tabular}{|l|c|c|c|c|c|c|c|c|c|c|c|}
\hline Climate Change- & \multicolumn{10}{|c|}{ Area } & \multirow{2}{*}{ Total\% } \\
\cline { 2 - 14 } Related Diseases & $\mathbf{1}$ & $\mathbf{2}$ & $\mathbf{3}$ & $\mathbf{4}$ & $\mathbf{5}$ & $\mathbf{6}$ & $\mathbf{7}$ & $\mathbf{8}$ & $\mathbf{9}$ & $\mathbf{1 0}$ & \\
\hline Cancer & 3.2 & 0.0 & 0.9 & 1.8 & 0.5 & 0.0 & 0.0 & 2.8 & 0.0 & 0.5 & 9.7 \\
\hline Malaria & 5.1 & 10.1 & 10.6 & 34.6 & 12.0 & 3.2 & 5.1 & 4.1 & 4.1 & 9.2 & 98.1 \\
\hline Typhoid & 5.1 & 7.8 & 10.6 & 31.3 & 12.0 & 3.2 & 4.6 & 4.1 & 4.1 & 8.8 & 91.6 \\
\hline Diarrhoea & 1.8 & 8.3 & 9.7 & 29.5 & 11.1 & 2.8 & 4.1 & 1.4 & 4.1 & 7.8 & 80.6 \\
\hline Cellulites & 2.3 & 0.0 & 1.4 & 1.8 & 0.9 & 0.0 & 0.0 & 1.8 & 0.0 & 0.5 & 8.7 \\
\hline Cholera & 3.7 & 6.0 & 9.7 & 25.3 & 9.7 & 1.8 & 2.8 & 2.8 & 2.8 & 7.4 & 72.0 \\
\hline Whitlow & 3.2 & 6.5 & 7.4 & 25.3 & 8.8 & 3.2 & 4.1 & 2.3 & 2.8 & 7.8 & 71.4 \\
\hline Pheumonia & 2.8 & 5.5 & 8.3 & 23.5 & 8.8 & 1.8 & 2.8 & 1.8 & 2.8 & 7.4 & 65.5 \\
\hline Meningitis & 2.3 & 5.1 & 6.0 & 17.5 & 6.5 & 1.4 & 2.3 & 1.8 & 2.3 & 3.7 & 48.9 \\
\hline Guinea worm & 1.8 & 5.1 & 6.0 & 19.8 & 9.7 & 1.8 & 2.8 & 1.4 & 2.8 & 5.5 & 65.8 \\
\hline Hypoglycemic & 1.8 & 7.4 & 8.8 & 24.4 & 6.9 & 3.2 & 2.3 & 1.8 & 3.7 & 5.5 & 65.8 \\
\hline
\end{tabular}




\begin{tabular}{|l|c|c|c|c|c|c|c|c|c|c|c|c|}
\hline \multicolumn{10}{|c|}{ Table 2: Contd., } \\
\hline Diabetes & 0.0 & 4.1 & 4.1 & 12.0 & 1.4 & 0.0 & 0.9 & 0.0 & 0.9 & 2.3 & 25.7 \\
\hline Disphonia & 0.0 & 0.9 & 0.5 & 2.3 & 0.0 & 0.0 & 0.5 & 0.0 & 0.5 & 0.5 & 5.2 \\
\hline Anaemia & 0.9 & 0.0 & 0.0 & 0.5 & 4.1 & 0.0 & 0.0 & 0.9 & 0.0 & 0.5 & 6.9 \\
\hline Hernia & 1.8 & 1.8 & 8.3 & 11.5 & 3.7 & 1.4 & 0.0 & 1.8 & 0.9 & 1.4 & 32.6 \\
\hline Conjuctivitis & 3.2 & 6.9 & 10.1 & 27.2 & 11.1 & 2.8 & 4.1 & 2.3 & 3.7 & 6.5 & 32.6 \\
\hline Asthma & 2.3 & 4.6 & 6.9 & 20.7 & 8.3 & 1.4 & 3.2 & 1.4 & 2.3 & 6.0 & 57.1 \\
\hline Syphilis & 2.3 & 3.2 & 6.9 & 16.6 & 8.3 & 1.8 & 2.3 & 1.8 & 1.8 & 3.7 & 48.7 \\
\hline Gastric problem & 3.2 & 6.9 & 8.8 & 24.0 & 8.8 & 1.8 & 2.8 & 2.3 & 2.8 & 5.1 & 66.5 \\
\hline Hypertension & 3.2 & 6.9 & 8.8 & 25.3 & 7.4 & 1.8 & 2.8 & 2.3 & 1.8 & 6.9 & 67.2 \\
\hline Beriberi & 2.8 & 6.5 & 9.2 & 26.7 & 7.8 & 2.8 & 4.1 & 1.8 & 4.1 & 7.4 & 73.2 \\
\hline Measles & 4.6 & 7.8 & 10.6 & 32.3 & 11.5 & 3.2 & 5.1 & 3.7 & 4.1 & 9.2 & 92.1 \\
\hline Cough & 5.5 & 10.1 & 10.6 & 34.6 & 12.0 & 3.2 & 5.1 & 4.6 & 4.6 & 9.2 & 99.5 \\
\hline
\end{tabular}

Source: Author's Field Work 2015

Key: Akata-1, Alapata-2, Arowomole-3, Ibapon-4, Ijeru1-5, Ijeru 2-6, Ilogbo-7, Isoko-8, Lagbedu-9, Okeola-10.

Literature affirms it that there is a connection between climate change, environment and health (Judith, 1993; Ayoade, 2003; The Guardian, 2016). Primary data were collected on some diseases to for the purpose of investigation and also to draw inferences for this research. The diseases that have the highest incidence are: cough (99.5), malaria (98.1), measles (92.1), typhoid (91.6), diarrhoea (80.6), beriberi (73.2) and cholera (72). There is a significant difference in the perceived incidence of diseases across the areas; however, the difference was not significant at 95\% confidence level. This implies that control of environmental quality has a significant influence on health. This control may include the alleviation of climate change parameters, especially temperature through greening and cooling of the environment.

Table 3: Health Data

\begin{tabular}{|c|c|c|c|c|c|c|c|c|c|c|c|c|}
\hline Diseases & 2006 & 2007 & 2008 & 2009 & 2010 & 2011 & 2012 & 2013 & 2014 & 2015 & Total & $\%$ \\
\hline Cancer & 15 & 15 & 16 & 7 & 6 & 11 & 45 & 3 & 22 & 53 & 193 & 1.93 \\
\hline Malaria & 238 & 109 & 194 & 208 & 148 & 123 & 264 & 265 & 349 & 407 & 2305 & 23.05 \\
\hline Diarrhoea & 71 & 129 & 53 & 49 & 48 & 57 & 100 & 77 & 122 & 129 & 835 & 8.35 \\
\hline Cellulite & 6 & 25 & 15 & 25 & 15 & 36 & 21 & 9 & 31 & 33 & 216 & 2.16 \\
\hline Whitlow & 7 & 3 & 16 & 10 & 14 & 32 & 25 & 25 & 32 & 37 & 201 & 2.01 \\
\hline Typhoid & 25 & 33 & 26 & 129 & 98 & 60 & 57 & 10 & 134 & 141 & 806 & 8.06 \\
\hline Meningitis & 73 & 131 & 55 & 51 & 50 & 59 & 102 & 79 & 124 & 131 & 855 & 8.62 \\
\hline Guinea worm & 20 & 11 & 4 & 3 & 1 & 27 & 4 & 9 & 37 & 42 & 158 & 1.58 \\
\hline Diabetes & 91 & 25 & 39 & 52 & 27 & 44 & 87 & 54 & 52 & 110 & 581 & 5.81 \\
\hline Anaemia & 94 & 140 & 189 & 168 & 172 & 177 & 262 & 176 & 234 & 243 & 1855 & 18.55 \\
\hline Hernia & 13 & 114 & 2 & 17 & 35 & 43 & 13 & 47 & 52 & 57 & 393 & 3.93 \\
\hline Asthma & 4 & 4 & 19 & 21 & 20 & 25 & 13 & 26 & 35 & 39 & 215 & 2.15 \\
\hline Measles & 17 & 17 & 4 & & 4 & 1 & 4 & 2 & 4 & 11 & 56 & 0.56 \\
\hline Cough & 6 & 5 & 4 & 2 & 2 & 2 & 3 & 1 & 24 & 7 & 56 & 0.56 \\
\hline Gastric problem & 4 & 10 & 3 & 15 & 14 & 5 & 22 & 39 & 23 & 22 & 155 & 1.55 \\
\hline Hypoglycaemia & 19 & 6 & 3 & 2 & 5 & 1 & 5 & 5 & 46 & 11 & 103 & 1.03 \\
\hline Hypertension & 21 & 22 & 49 & 77 & 44 & 34 & 83 & 91 & 53 & 100 & 574 & 5.74 \\
\hline Conjunctivitis & & 24 & & 1 & & 3 & 2 & 3 & 5 & 13 & 51 & 0.51 \\
\hline Pneumonia & 121 & 57 & 87 & 104 & 62 & 49 & 95 & 82 & 119 & 131 & 907 & 9.07 \\
\hline
\end{tabular}

Source: State Hospital Sun-Sun Ogbomoso 2015.

Over the period of ten years, despite that the incidence of some of the investigated diseases dwindled, it may yet be conveniently deduced that many of the hypothesized diseases have been on the increase. While malaria (2305) anemia (1855), meningitis (855), diarrhea (835) and typhoid (806) could be observed to have rapid increase, other diseases have 
also increased. For a clearer picture, the graph of morbidity trend was plotted to show how the incidence gravitated through the decade.

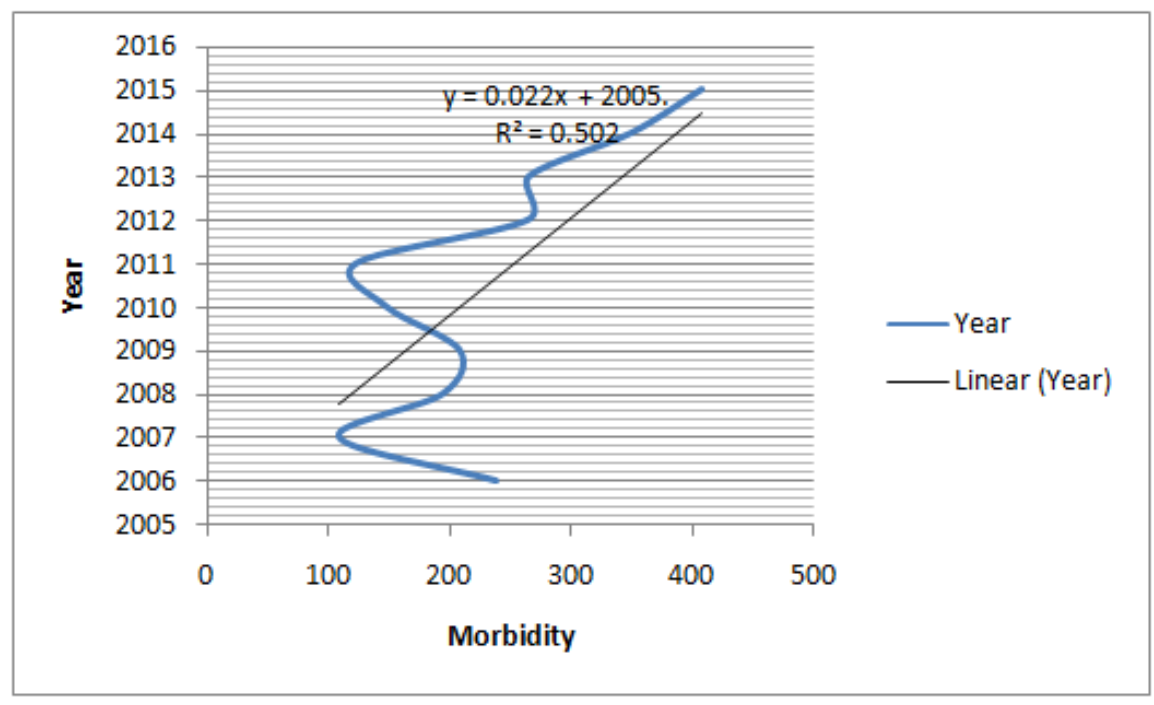

Figure 2: Morbidity Trend 2006-2015

Source: Author's device, 2016

A cursory observation of the graph shows a high annual upward review of the climate change-related diseases. This pattern of increase in the incidence of climatic elements as well as the related disease informed the hypothesis that climate change may have connections with residents' health. This hypothesis was tested using the linear regression analysis.

\section{Relationship between Climate Change and Residents' Morbidity}

The mean value of climate parameters was regressed to those of residents' morbidity and the result is presented in table 4. With the $\mathrm{F}$ value of 23.133 and $\mathrm{P}$ value of. 061 and having a regression coefficient of correlation of. 68 at $95 \%$ confidence level; it may be concluded that there is a reliable relationship between the two, only that it is not significant statistically. The coefficient of determination $\left(\mathrm{R}^{2}=.462\right)$ suggests that there is $46.2 \%$ overlap between climate change and morbidity.

Table 4: Regression Analysis

\begin{tabular}{|c|l|l|c|c|c|c|c|c|c|}
\hline SN & Dependent & Independent & $\mathbf{R}$ & $\mathbf{R}^{2}$ & F & P. Value & \multicolumn{2}{|c|}{ B } & P Value \\
\hline 1 & $\begin{array}{l}\text { Residents } \\
\text { Morbidity }\end{array}$ & $\begin{array}{l}\text { Climate } \\
\text { Change }\end{array}$ & .68 & .462 & 23.133 & .062 & $\begin{array}{l}\text { Constant } \\
\text { Environmental } \\
\text { Education }\end{array}$ & $\begin{array}{c}47.143 \\
1.18\end{array}$ & .007 \\
.084
\end{tabular}

Source: Author's computation 2016.

This implies that climate change has a reliable relationship with residents' health in the study area. Although there are other factors of climate change and health left unaccounted for, climate change has the propensity up to $46.2 \%$ to influence residents' health.

Calibrating the model, therefore, we have:

$$
y=a+b x+e
$$


Where: $\mathrm{y}=$ Dependent variable (Residents morbidity)

$$
\begin{aligned}
& a=\text { Constant } \\
& b=\text { Regression coefficient of the Independent variable } \\
& X=\text { Climate change (Independent variable) }
\end{aligned}
$$

The relationship is therefore given by:

Residents' Morbidity $=47.143+1.18$ (Climate Change $)+\mathrm{e}$

From the equation above, a unit increase in climate change will produce a corresponding 1.18 increase in residents' morbidity. The planning implication is that a significant reduction in climate change and variability tendencies is indispensable to improving residents' health in the study area. Invariably, if we want residents' health to improve by a maximum of $46.2 \%$, we need to return the changed climate to what it used to be. This implies that; temperature has to be lowered by at least $1.5 \mathrm{C}$ every decade. Rainfall, humidity and the rest of the parameters of climate change would return to what they were

\section{RECOMMENDATIONS AND CONCLUSIONS}

Climate change, though looking slow in pace is doubling up by the decades. It has been seen in this study that it has a lot of propensity to affect human health. This health issue is more problematic in Africa, where health facilities are grossly inadequate. The causes and impact of climate change to health have been discussed; these changes are largely caused by human activities, mainly the burning of fossil fuels releasing carbon dioxide $\left(\mathrm{CO}_{2}\right)$ that traps heat within the atmosphere. Human-induced climate change is an emerging threat that rightly commands widespread policy and public attention. Along with other rapid changes associated with global population and economic growth, climate change strains existing weak points in health protection systems and calls for reconsideration of public health priorities. The most effective responses are likely to be strengthening of the key functions of environmental management, surveillance and response safeguard health from natural disasters and changes in infectious disease patterns, and a more pro-active approach to ensure that development decisions serve the ultimate goal of improving human health. Some of the suggestions towards these are:

Environmental Education and Management: A conscious effort to reducing climate change faces all directions. Every hand must be on deck. This gives everyone a role or more to play in our fight to save the mother earth in terms of climate change reduction. This requires public education on the implications of human activities and the need for conscious and cautious environmental management

Environmental Greenery: Green plant photosynthetic activities have been observed to be a reliable panacea to the accumulation of heat trapping $\mathrm{CO} 2$. Encouraging environmental greenery through: soft residential landscaping, sustainable urban agriculture, creation of parks and gardens in the city scale and a conscious conservation practice in terms of forestry, recycling, and other best practices would go a long way to slow down the rate of climate change and therefore enhance sustainable healthy cities.

\section{REFERENCES}

1. Adeowu, B.M. (2005) “Urban Environmental Planning and Management”, An Unpublished Area Paper, Department of Urban and Regional Planning, University of Ibadan Press, Ibadan. 
2. Agbola, T and Kassim, F. (2007): “Conceptual and Theoretical Issues in Housing”. In Agbola T; Egunjobi L. And Olatubara C.O.(eds). Housing Development and Management: A book of Readings: Department of Urban and Regional Planning, University of Ibadan, Ibadan.

3. Agbola, T. and Oladoja, A. (2001), “Philosophy and Theory of Urban and Regional Planning”. In Tunde Agbola (ed). Readings in Urban and Regional Planning. Macmillan Nigeria Publishers Ltd, Ibadan. Pg. 1-28.

4. Agbola, T. And Adeniyi, O. (2008), Global Warmimg and Environmental Degradation: The Challenges for sustainable Environmental Development in Nigeria'. Being the Lead Paper Presented at the National Conference Organized by the School of Environmental Studies, Federal Polytechnic, Ado-Ekiti.

5. Akpokure, M.F and Omisore, E.O (2009): The Environmental Implication of Petrochemical Discharges on the Mangrove Ecosystem in Ubeji-Warri Area of Delta State. Ife Journal of Environmental Design and Management: Nigeria. Volume 2 Number 1.pgs 31-32, March 2009.

6. Alexander, L. V (2006): Global observed changes in daily climate extremes of temperature and precipitation. Journal of Geophysical Research, 111, 22, doi: 10.1029/2005JD006290. URL| Detail

7. Alley, Richard B. (2002) "Anorthern lead in the orbital band: north-south pleasing of Ice-Age events (h//p://www.ingentaconnect.com/content/els/02773791/2002/00000021/00000001/art 00072)'”.

8. Ayoade, J.O (2003) Climate Change: A Synopsis of its Nature, Causes Effects and Management. Vantage Publishers: Ibadan, Nigeria.

9. Berger, A. et al (2005) "On the origin of the 100-kyr cycles in the astronomical forcing", (http://www.agu.org/pubs/crossref/2005/2005PA00173. html)Paleoceanography 20 (4). PA4019. Retrieved 2008-06-20.

10. Bush, G.W. (2001) Text of a letter from the President to Senators Helms, Craig, and Roberts (http://www.whitehouse.gov/news/releases/2001/03/20010314.html). Office of the Press Secretary.Retrieved on 2008 on 200806-20.

11. Dodman, D.Hug, S.and Satterthwaite, D.(2009). The Contribution of Urban Areas to Climate Change. UN-Habitat Global Report on Human Settlements 2011.

12. Environmental Protection Agency (2010), Our Nation's Air: Status and Trends Through U.S Environmental Protection Agency, EPA-454/R-09-002.

13. Genthon, C. et al (1987) "Vostok Ice Core-Climate response to CO2 and orbital forcing changes over the last climate cycle(http://www.nature.com/naturo/journal/v329/n6138/abs/329414ao.html)' Nature 329 (6138): 414-418. Retrieved 200806-20

14. Gates, E.S. (1972) Meteorology and Climatology for the sixth form and beyond (4 $4^{\text {th }}$ edition), Harrap, London.

15. Girardet, H. (1998). Sustainable Development: A Contradiction in Terms. In Fernandes, E. (ed) Environmental Strategies for Sustainable Development in Urban Areas: Lessons from Africa and Latin America, Aldershot, Ashgate.

16. Intergovernmental Panel on Climate change (2007), Aviation and the global atmosphere: A special report of the intergovernmental panel on climate change, Cambridge University press, Cambridge.

17. Intergovernmental Panel on climate Change (2001), Summary of policy makers(http//www.grida.no/climate/ipcctar/wg1/006.htm.) Climate change 2001: The Scientific Basis, Contribution of Working Group 1 to the Third Assessment Report of the Intergovernmental Panel on Climate Change. Retrieved 2008-06-20.

18. IPPC (2006) "Specail Report on Emissions Scenarios", Resource Availiability 
(http//www.enda.No/climate/ipcc/emission104.htm).Retrieved on 2008-06-20.

19. IPPC WGI AR4 Report (2007) chapter 1: Historical Overview of Climate Change Science. (http://ipccwg1.ucar.edu/wg1/Report/ARWG1-Print-ch01.pdf) IPCC WGI AR4 Report, p.97 (pdf page 5 of 36). IPCC (2007).Retrieved on 2008-06-20.

20. John M.B, (2007)(http://www.neihs.nih.gov/about/od/advisor/Balbus/index.cfm).

21. Judith T. Parrish (1993), "Climate of the Supercontinent Panagea”. Chemical Geology (The University of Chicago Press) 101(2): 215-233. JSTOR 30081148.

22. Kiehl, J.T and Kevin E.T (1997) “Earth's Annual Global Mean Energy Budget (http://www.atmo.arizona.edu/students/courselinks/spring04/atmos4516/pdf/RadiationBudget.pdf)" Bulletin of the American Meteorological Society 78(2): 197-208. Retrieved on 2008-08-08.

23. Lockwood, J.G. (1979) Causes of Climate.E.Arnold, London.

24. McGuffie and A. Henderson-Seller (1997); A Climate Modelling Primer, $2^{\text {nd }}$ Edition. John Wiley: London.

25. Mungal (2007): Intergovernmental Panel on Climate Change; The Physical Science Basis (Summary for policy maker.), IPCC.

26. Ojeleye, D.A. (2006) Climate Change and Food Crop Production in Ibadan: An Unpublished Masters Dissertation Submitted to the Department of Urban and Regional Planning (MURP), Faculty of the Social Sciences, University of Ibadan, Ibadan.

27. Paleoaltimetry incorporating atmospheric Physics and botanical estimates of paleoclimate'. Geological society of America Bulletin 111(4): 497-511.

28. Paul R.Epstein, (2005). England Journals of Medicine 353: 1433-1436 October 6, 2005.

29. Pearson, Paul N. And Palmer, Martin R (2000) "Atmospheric carbon dioxide concerntrations over the past 60 million years(http://www.nature.com/nature/journal/v406/n6797/abs/406695a0.html)"” $\quad$ Nature $406 \quad$ (6797):695699.doi:10.1038/35021000 (http//dx.doi.org/10.1038/35021000).

30. Prentice, I. Colin et al (2001)SRES scenarios and teir implications fo future CO2 concentration (http://www.gnda.no/climate/ipcc-tar/wg1/123.htm) Climate Change 2001: The Scientific Basis Contribution of Working Group 1 to the Third Assessment Report of the IPCC. Retrieved on 2008-06-20.

31. Rees, W. (1992) Ecological Footprints and Appropriated capacity, What Urban Economic Leaves Out, Environment and Urbanization, 4(2): 121-130.

32. The Guardian (2016); Nasa: Earth is Warming at a Pace Unprecedented in 1,000 Years https://www.theguardian.com/environment/2016/aug/30/nasa-climate-change-warning-earth-temperature-warming

33. UN News Center (2016); 2016 on Pace to be Hottest Year ever as Climate Change Trends Reach New climaxhttp://www.un.org/apps/news/story.asp?NewsID=54520\#.WEmXoKJp5Sk

34. USGCRP (2009) Global climate change impacts in the United States. Karl, T.R. J.M. Melillo, and T.c Peterson (eds). United States Global Change Research Program. Cambridge University Press, New York. USA.

35. Uwejamomere, T. (2003) Climate Change in Nigeria: A Communication Guide. Nigerian Environmental Study/ Action Team (NEST) 